\title{
Electrochemical corrosion of cast iron pipes in reclaimed water containing disinfectant
}

\author{
Haiya Zhang ${ }^{1,2}$, Yimei Tian ${ }^{1, *}$, Hao Guo ${ }^{1}$, Mengxin Kang ${ }^{1}$, Yarong Song ${ }^{1}$ \\ ${ }^{1}$ School of Environmental Science and Engineering, Tianjin University, Tianjin 300350, China \\ ${ }^{2}$ School of Environment, Tsinghua University, Beijing 100084, China \\ *E-mail: ymtian_2000@126.com
}

doi: $10.20964 / 2018.09 .74$

Received: 30 January 2018 / Accepted: 13 June 2018 / Published: 5 August 2018

\begin{abstract}
The corrosion characteristics of cast iron pipes in reclaimed water containing 1,2 , and $4 \mathrm{mg} / \mathrm{L} \mathrm{NaClO}$ and $\mathrm{ClO}_{2}$ were investigated using potentiodynamic polarization curves (PPCs) and electrochemical impedance spectra (EISs). Scanning electron microscopy (SEM) was also used to evaluate the morphology of the corrosion scales. The results showed that $\mathrm{NaClO}$ and $\mathrm{ClO}_{2}$ utilization changed the electron-transfer pathway and corrosion-product characteristics significantly. In reclaimed water containing $\mathrm{NaClO}$ at 1,2 , and $4 \mathrm{mg} / \mathrm{L} \mathrm{HClO}$ could take precedence over dissolved oxygen (DO) to react with $\mathrm{Fe}$ and enhance the corrosion process at 4 days. However, the consumption of $\mathrm{NaClO}$ caused a shortage of $\mathrm{HClO}$ reacting with iron and induced the re-passivation of previously eroded areas at 30 days in the $1 \mathrm{mg} / \mathrm{L} \mathrm{NaClO}$ experiments. Furthermore, high concentrations of $\mathrm{NaClO}(2$ and $4 \mathrm{mg} / \mathrm{L}$ ) also enhanced the corrosion process at 30 days. In the 1,2 , and $4 \mathrm{mg} / \mathrm{L} \mathrm{ClO} \mathrm{Cl}_{2}$ experiments, the $\mathrm{ClO}_{2}$ molecule could take precedence over $\mathrm{DO}$ to react with the $\mathrm{Fe}$ and formed iron chlorides, enhancing the uniform corrosion throughout the whole experiment. Additionally, iron oxides or iron hydroxides usually showed a compact, needle-like structure in the control experiments, while flocculated iron chlorides were the main components in the disinfection experiments. Moreover, the acidification caused by $\mathrm{H}^{+}$accumulation initiated distinct localized corrosion after 4 days of immersion in the 2 and $4 \mathrm{mg} / \mathrm{L} \mathrm{ClO}_{2}$ experiments, earlier than that in $\mathrm{NaClO}$ experiments (30 days). Thus, from a corrosion control perspective alone, $\mathrm{NaClO}$ is a better disinfection choice than $\mathrm{ClO}_{2}$.
\end{abstract}

Keywords: disinfectant; electrochemical corrosion mechanism; cast iron; reclaimed water; corrosion scales;

\section{$\underline{\text { FULL TEXT }}$}

(C) 2018 The Authors. Published by ESG (www.electrochemsci.org). This article is an open access article distributed under the terms and conditions of the Creative Commons Attribution license (http://creativecommons.org/licenses/by/4.0/). 